\title{
TP53 NM_000546.5:c.741_742delCCinsTT
}

National Cancer Institute

\section{Source}

National Cancer Institute. TP53 NM 000546.5:C.741 742de/CCinsTT. NCI Thesaurus. Code C146905.

A complex substitution where the nucleotide sequence at positions 741 and 742 of the coding sequence of the TP53 gene has changed from cytosine-cytosine to thyminethymine. 